\title{
ДВОВИМІРНА ТИПОЛОГІЯ СИНТАКСИЧНО НЕЧЛЕНОВАНИХ ОДИНИЦЬ В УКРАЇНСЬКОМУ МОВОЗНАВСТВІ
}

\author{
МАРІЯ ЛИЧУК \\ Національний університет біоресурсів і природокористування України, \\ Київ - Україна \\ mariya.lychuk@gmail.com; ORCID: 0000-0002-8046-7414 \\ DWUWYMIAROWA TYPOLOGIA \\ JEDNOSTEK NIEPODZIELNYCH SYNTAKTYCZNIE \\ W JĘZYKOZNAWSTWIE UKRAIŃSKIM
}

\begin{abstract}
MARIA ŁYCZUK
Narodowy Uniwersytet Zasobów Biologicznych i Naturalnych Ukrainy, Kijów — Ukraina

STRESZCZENIE. W artykule określono formalne i semantyczne zasady hierarchizacji jednostek niepodzielnych syntaktycznie. Uzasadniono typologie strukturalne syntaktycznie niepodzielnych połączeń wyrazowych i niefrazeologizowanych oraz frazeologizowanych niepodzielnych zdań. Usystematyzowano semantyczne typy syntaktycznie niepodzielnych połączeń wyrazowych i syntaktycznie niepodzielnych zdań.

Słowa kluczowe: syntaktycznie niepodzielne połączenie wyrazowe, niefrazeologizowane niepodzielne zdanie, frazeologizowane zdanie, typ strukturalny, typ semantyczny, typologia dwuwymiarowa.
\end{abstract}

\section{TWO-DIMENSIONAL TYPOLOGY OF SYNTACTICALLY UNCROWNED UNITS IN UKRAINIAN LINGUISTICS}

\author{
MARIIA LYCHUK \\ National University of Life and Environmental Sciences of Ukraine, Kyiv — Ukraine
}

ABSTRACT. The formal and semantic principles of the hierarchy of syntactically non-segmented units have been determined. The structural typologies of syntactically nonsegmented word combinations and unphraseologized and phraseologized non-segmented sentences have been substantiated. The semantic types of the non-segmented word combinations and syntactically non-segmented sentences have been systematized.

Key words: syntactically non-segmented word combination, unphraseologized actually non-segmented sentence, phraseologized non-segmented sentence, structural type, semantic type, two-dimensional typology.

\footnotetext{
ктуальність дослідження зумовлена потребою цілісного вивчення й упорядкування структурних і семантичних типів нечленованих синтаксич1 них одиниць. Створення структурної та семантичної типологій синтаксично нечленованих одиниць сприятиме розв'язанню проблемних питань функційної синтаксичної теорії, зокрема визнанню в синтаксичній системі сучасної української літературної мови синтаксично нечленованих одиниць як нормативних та розв’язанню дискусійних проблем, що стосуються специфічної білатеральної структури фразеологізованих нечленованих речень.
} 
Мета цієї наукової розвідки - створити двовимірну типологію синтаксично нечленованих одиниць сучасної української мови. Мета зумовлює розв'язання таких завдань: 1) визначити принципи систематизації нечленованих синтаксичних одиниць; 2) схарактеризувати формальну та семантичну диференціацію синтаксично нечленованих одиниць.

У лінгвоукраїністиці типологія синтаксично нечленованих одиниць уможливила інтегрувати в єдину систему два класи синтаксичних одиниць - синтаксично нечленовані словосполучення й синтаксично нечленовані речення. Ці синтаксичні одиниці наділені основними ознаками - синтаксичною зв'язаністю й синтаксичною нечленованістю.

У функційній граматиці української мови традиційною $є$ типології синтаксично вільних словосполучень та формально-граматичних речень за формальним і семантичним принципами. Однак ці типології не поширені на синтаксично нечленовані словосполучення й синтаксично нечленовані речення, оскільки ці синтаксичні одиниці не були об'єктом вивчення в лінгвістиці.

Теорія словосполучення як учення про самостійну синтаксичну одиницю сформувалася в українському мовознавстві в 60 -х роках XX ст., а грунтовні дослідження синтаксично нечленованих словосполучень з'явилися в граматичних студіях тільки в першому десятиріччі XXI ст.

Словосполучення як синтаксична одиниця-конструкція, як відомо, характеризується планом вираження, тобто граматичною формою, і планом змісту, тобто граматичним значенням.

У сучасній лінгвоукраїністиці немає єдиного випрацьованого підходу до виокремлення типів синтаксично нечленованих словосполучень. Лінгвісти диференціюють їх за морфологічною належністю складників, граматичним значенням, ступенем злитості складників та ін. У зарубіжній лінгвістиці за ознакою злитості компонентів розглядали вільні й тісні словосполучення ${ }^{1}$. Аналізуючи компоненти тісних словосполучень, голландський лінгвіст $Є$. Крейзінга виділяв синтаксично головне слово ${ }^{2}$. Німецький дослідник I. Ріс назвав тісні словосполучення терміном wortgruppen (словесні групи) ${ }^{3}$ та розглянув ознаку злитості слів у словосполученнях - словесних групах, наголошуючи, що форма і функція мають стосунок не до окремих компонентів, а до всієї словесної групи. За ступенем злитості I. Ріс виділив три основні розряди словосполучень: 1) слабкі групи - сурядні словосполучення; 2) напівтісні групи - це сполучення на зразок інженер Михайлов; Михайлов, інженер; 3) тісні групи - словосполучення з підрядним зв'язком між словами ${ }^{4}$.

Дослідники оперують ступенем семантичної злитості компонентів як головним критерієм у процесі виокремлення семантико-синтаксичних єдностей в семантично неподільних (нечленованих) словосполучення $\mathrm{x}^{5}$.

Синтаксично нечленовані словосполучення зумовлені ономасіологічними характеристиками частиномовного статусу їхніх ядерних компонентів, а саме: іменників, прикметників, числівників, займенників та дієслів, особливостями їхної семантики та категорійних значень, а також репрезентативними можливостями в номінативному аспекті.

\footnotetext{
${ }^{1}$ E. Kru ising a, Hand book of Present-day English Noordhoff, Groningen 1931, Vol. 3, p. 5.

${ }^{2}$ Ibidem.

${ }^{3}$ I. Ri es, Was ist syntax (ein kritischer Versuch), Marburg 1894, p. 19.

${ }^{4}$ Ibidem, p. 19-20.

${ }^{5}$ А. П. Загнітко, Теоретична граматика украӥнської мови. Синтаксис, Донецьк 2001,
} c. 63-64. 
У сучасному мовознавстві не випрацьовано єдиних критеріїв типології синтаксично нечленованих словосполучень. Найпослідовніше дослідники виділяли кількісно-іменні конструкції (два дні, кілька хвилин, иматок хліба) та словосполучення зі значенням сумісності (ми з мамою, дівчина з подругами, Остап із Соломією). Дехто з учених зараховував до синтаксично нечленованих словосполучення зі значенням вибірковості (дехто з нас, хто-небудь з учених, нікого із сусідів) та поєднання модальних або фазових дієслів з інфінітивом (можу робити, почав писати) $)^{6}$. В. Горпинич як два типи синтаксично нечленованих словосполучень розглядав метафоричні й перифрастичні словосполучення?

Формальна типологія як синтаксично вільних, так і синтаксично нечленованих словосполучень грунтується на таких характеристиках, як форма (спосіб) синтаксичного зв'язку, елементарність / неелементарність структури, морфолого-синтаксичні ознаки компонентів, а семантична типологія оперта на тип семантико-синтаксичного відношення між головним і залежним компонентами ${ }^{8}$.

У лінгвістиці докладно описані формальні типи синтаксично вільних словосполучень. Теоретичні засади дослідження обсягу словосполучення були закладені в працях В. Виноградова, який визначив прості і складні словосполучення як граматичні поєднання двох і більше повнозначних слів, що розчленовано позначають єдине поняття. При цьому диференціація словосполучень на прості й складні здійснюється 3 опертям на поширювальні властивості слова: „Прості словосполучення звичайно двослівні, вони складаються 3 двох повнозначних слів... Характерною ознакою таких словосполучень $\epsilon$ те, що вони утворюються за допомогою поширення стрижневого слова" (перекл. автор. - М. Л.) ${ }^{9}$. Складні словосполучення $є$ результатом поширення простого словосполучення; їхні межі визначені можливістю бути єдиним, хоч і складним, позначенням предметів, дій, якостей та ін.

Розвиваючи погляди В. Виноградова, М. Прокопович проаналізував складні словосполучення, у яких просте словосполучення виконує роль залежного компонента. Він зазначав: ,Залежне слово в поширювальному простому словосполученні (що займає позицію нерозчленованого залежного компонента щодо стрижневого слова) граматично і за змістом пов'язане з головним (стрижневим) словом тільки цього простого словосполучення. Лише через нього в його складі воно пов'язується з головним, стрижневим словом усього складного словосполучення" (перекл. автор. - М. Л.) ${ }^{10}$. Напр.: дім з (білими) колонами - дім з колонами, але: суддя з блідим обличчям. М. Прокопович наголосив, що обсяг словосполучення передусім визначається з погляду мінімальної кількості його компонентів, що найпростіше, двослівне словосполучення покладено в основу словосполучень ускладненої структури.

${ }^{6}$ В. О. Горпинич, Нерозкладні синтаксичні словосполучення в украӥнській мові, [в:] „Українська мова і література в школі”, 1988, № 7, с. 69-70.

${ }^{7}$ Там само.

${ }^{8}$ I. Р. В ихо в ан ець, Граматика украӥнської мови: Синтаксис, Київ 1993, с. 210.

${ }^{9}$ В. В. Виноградов, Вопросы изучения словосочетаний, [в:] „Вопросы языкознания”, 1954, № 3, c. 10 .

${ }^{10}$ Н. Н. Прокопо в ич, Об устойчивых сочетаниях аналитической структуры в русском языке советской эпохи, [в:] Мысли о современном русском языке, ред. В. В . В и н огр адо в, Москва 1969, с. 69. 
За елементарністю / неелементарністю будови розрізняли елементарні й ускладнені (неелементарні) словосполучення ${ }^{11}$, прості і складні ${ }^{12}$. У лінгвоукраїністиці усталеною $є$ типологія словосполучень за частиномовною належністю опорного та залежного компонентів.

3 урахуванням формально-синтаксичних і семантико-синтаксичних ознак I. Вихованець розмежував прості та ускладнені словосполучення. Він кваліфікував прості словосполучення як основний і первинний об'єкт синтаксису, називав їх елементарними. Їхня структурна схема здебільшого представлена двома компонентами, що поєднані підрядним або сурядним зв'язком (синє небо, книга поета, напружено працювати, батьки й діти). Елементарне словосполучення має формально-синтаксичну й семантико-синтаксичну організацію, тобто будується за певною структурною схемою (структурним зразком), що репрезентує абстрактну формулу, за якою оформляються численні словосполучення 3 різним лексичним наповненням компонентів ${ }^{13}$. Ускладнені словосполучення I. Вихованець витлумачив як різноманітні об'єднання елементарних словосполучень на основі підрядного або сурядного зв'язків. Такі синтаксичні конструкції охоплюють численні комбінації елементарних словосполучень і складаються мінімально 3 трьох компонентів ${ }^{14}$.

У лінгвоукраїністиці досі не створено єдиної типології синтаксично нечленованих словосполучень. Спираючись на погляди I. Вихованця, услід за М. Балко, уважаємо синтаксично нечленовані словосполучення ускладненими, „оскільки, по-перше, у них більше, ніж один раз, реалізується підрядний зв'язок, а по-друге, вони становлять результат різних дериваційних перетворень" 15 .

М. Балко пропонує поділити всі синтаксично нечленовані словосполучення на дві групи: а) які зберігають ознаку зв'язаності як у контексті, так і поза ним; б) синтаксична зв' язаність яких детермінована їхньою функційно-семантичною специфікою та простежується лише в реченнєвій структурі ${ }^{16}$. Однак зауважимо, що ознаку синтаксичної зв'язаності не можна вважати прозорим і чітким критерієм розмежування двох груп, оскільки в деяких типах синтаксично нечленованих словосполучень таку ознаку не можна простежити поза контекстом, напр.: дещо з використовуваних раніше документів, у кіниі невеликого села, з мигдалевидними очима, скрипучим голосом та ін.

Наш підхід до аналізу синтаксично нечленованих словосполучень грунтується на "підході зверху", тобто від речення, що вможливлює подати словосполучення як таке, що з'являється в процесі реалізації речення, у процесі розгортання компонентів тієї чи тієї структурної схеми під час побудови висловлення. Виокремлюємо два структурні типи синтаксично нечленованих словосполучень: двокомпонентні і трикомпонентні. Двокомпонентним синтаксично нечленованим словосполученням уважаємо структурно-семантичну неподільну єдність, утворену з двох повнозначних слів без прийменника або з прийменником на основі синтаксичного зв'язку, що увиразнений синтаксичною зв'язаністю,

${ }^{11}$ I. Р. Вихованець, Граматика украӥнської мови..., с. 211.

${ }^{12}$ К. Ф. Шульжук, Синтаксис украйнської мови, Київ 2004, с. 38-39.

${ }^{13}$ I. Р. В ихов анець, Граматика украйнськой мови..., с. 192.

14 Там само, с. 196.

15 М. В. Балко, Актуальні проблеми теорії словосполучення сучасної української мови, Дніпропетровськ 2014, с. 151.

${ }^{16}$ М. В. Балко, Семантико-синтаксичні і структурні аспекти иілісних словосполучень сучасної української мови, дис. ... канд. філол. наук, Запоріжжя 2004, с. 26-28. 
та відповідних семантико-синтаксичних відношень між компонентами структурної схеми. Напр.: Та моя цүікавість була заспокоєна швидше: ще взимі батько взяв мене одного понеділка до Дрогобича, і тут я побачив иүілі юрби ріпників i иүілі купи жсидів (I. Франко); Сотні очей пристрасно стежсили за иим геройчним переходом танків по дну чужої ріки (О. Гончар). Трикомпонентне нечленоване словосполучення має атрибутивний поширювач до залежного компонента, що виражений прикметником або займенником. Облігаторний третій компонент виконує доповнювальну функцію - звужує загальну семантику словосполучення, напр.: Деві після деякого моменту вагання вертається на їі крик $і$ кидається в ї̈ обійми (Леся Українка); Хтось з досвідчених сільських бувальців порадив Аркадію запустити бороду... (Ірина Вільде).

Злитість компонентів синтаксично нечленованого словосполучення має синтаксичний характер: вони зберігають своє лексичне значення, у межах неподільної єдності реалізований синтаксичний зв'язок, підсилений синтаксичною зв’ язаністю, та відповідні семантико-синтаксичні відношення. За цими ознаками кваліфікуємо синтаксично нечленовані словосполучення як ускладнені.

У виділенні типів словосполучень за семантичним критерієм лінгвісти зважали на спільність синтаксичного змісту. У сучасній лінгвоукраїністиці сформовано два підходи до типології синтаксично вільних словосполучень за семантико-синтаксичними відношеннями. Представники першого підходу ${ }^{17}$ виокремили три типи синтаксично вільних словосполучень: 1) атрибутивні (означальні) — відношення ознаки до предмета, напр.: обдарований художник, зошит учня та ін.; 2) субстанціальні - відношення предмета до дії, процесу, стану та інших ознак, напр.: принести води, писати лист матері та ін.; 3) адвербіальні - відношення обставини до дії, стану, якості та ін., напр.: працзювати влітку, творити для прийдешнього та ін.

Запропонована типологія словосполучень має надто узагальнений характер і не може бути поширена на типологію синтаксично нечленованих словосполучень.

На думку деяких лінгвістів (Н. Шведової, А. Загнітка) комплетивні відношення ідентифікують синтаксично нечленовані словосполучення в синтаксичній системі мови ${ }^{18}$. Комплетивні відношення трактуємо як тип семантикосинтаксичного відношення, яким пов'язаний ядерний і залежний компоненти для інформативного доповнення першого у структурі синтаксично нечленованого словосполучення.

Ураховуючи складність і неоднозначність виокремлення типів семантикосинтаксичних відношень у синтаксично нечленованих словосполученнях, спираючись на концепцію М. Балко ${ }^{19}$, виділяємо дві семантичні групи: 1) власнекомплетивні; 2) синкретичні нечленовані. Власне комплетивні відношення $\epsilon$ основним засобом вираження граматичного значення в семантичній структурі синтаксично нечленованих словосполучень. Вони увиразнюють властивість цих словосполучень займати синтаксичну позицію одного члена речення. Компоненти синтаксично нечленованого словосполучення, пов'язані власнекомплетивними відношеннями, більшою мірою виявляють інформативну недостатність, якщо розглядати їх уживання окремо. Напр.: словосполучення

${ }^{17}$ I. Р. В их о в анець, Граматика украӥнської мови..., с. 207-208.

${ }^{18}$ Русская грамматика: Синтаксис, в 2 томах, гл. ред. Н. Ю.Ш в едов а, Москва 1980, т. 2, с. 16-19; А. П. Загнітко, Теоретична граматика української мови..., с. 17.

${ }^{19}$ М. В. Балко, Семантико-синтаксичні і структурні аспекти иүілісних словосполучень..., c. $42-48$. 
3 власне-кількісним значенням, ядерний компонент яких виражений власнекількісним або збірним числівником: Поїздку було приурочено до символічної подї: двадиять п'ять років тому Польщза першою серед іноземних держав визнала незалежність України (Український тиждень, 09-15.09.16); Троє візитеpiв залишилися у їдальні (Брати Капранови); словосполучення зі значенням сумісності: Чоловік з жінкою сиділи так, наче прожили довге й терпке життя... (Я. Лижник); Ми з Валею загоряли (Б. Жолдак); словосполучення зі значенням вибірковості: Сказав, щзо хтось із села телефонував їй, здається, просив приїха$m u$ (В. Габор). Синкретизм семантико-синтаксичних відношень у нечленованих словосполученнях виявляється в можливості чи здатності одночасно поєднувати декілька значень. Синкретичні нечленовані словосполучення грунтуються на комплетивних відношеннях, які поєднуються з іншими семантичними відношеннями - атрибутивними, об' єктними чи атрибутивно-об' єктними. Напр.: комплетивно-атрибутивні - із залежним компонентом абстрактної семантики: Війна - річ дуже небезпечна... (Б. Жолдак); Учора на прощзання війт із тхориними - швидкими й боязкими - очима також попросив для пораненого мадяра мазі (М. Матіос); комплетивно-об'єктні - словосполучення з кількісним значенням: Пождавши марно, міняє голос: - Їсти хочеш $і$ сім'я теж. Я нагодую! - Повернув обличчя до гурту $і$ звелів: - Мішок пшениці! (В. Барка); словосполучення із загальним партитивним значенням: На цей час вони прибрали до рук ледь не половину кооперативів (О. Ульяненко); комплетивноатрибутивно-об' єктні - метафоричні та перифрастичні нечленовані словосполучення: Він блукає у зграях дерев, пролітає вітерець, видмухнувши із віт пахощуі квіту (Б. Жолдак). Однак розглянуті принципи систематизації словосполучень не можна визнати досконалими. Формальний і семантичний критерії окремо не створюють уявлення про синтаксично нечленоване словосполучення як про синтаксичну конструкцію, для якої характерна єдність плану вираження i плану змісту. Тому ми запропонували двовимірну типологію синтаксично нечленованих словосполучень - структурну й семантичну.

Синтаксична концепція, покладена в основу визначення синтаксично нечленованих речень, та їхня функція в українському літературному мовленні $\epsilon$ тими чинниками, що вможливили створення структурної та семантичної типологій нечленованих побудов.

Клас синтаксично нечленованих речень об'єднує різні типи: нефразеологізовані власне-нечленовані, фразеологізовані власне-нечленовані, або фразеологізовані тавтологійні, напівфразеологізовані та частково фразеологізовані речення. Вихідною базою для створення структурних типологій нефразеологізованих і фразеологізованих нечленованих речень слугують особливості структурних компонентів або фразеологізованих структурних схем. Структурні типи нефразеологізованих власне-нечленованих речень виокремлюємо, зважаючи на кількість компонентів структури, морфологічну природу структурних компонентів, а фразеологізованих нечленованих речень - залежно від облігаторних постійного і змінного компонентів фразеокомплексу, їхнього частиномовного вираження та позиції постійного компонента.

Нефразеологізовані власне-нечленовані речення утворені зі слів і семантично еквівалентних їм фразеологізмів, що виражають непоняттєве значення, чи зі слів, що втратили номінативність через переосмислення в разі вживання їх як самостійного висловлення. Абсолютна морфологічна й синтаксична нечленованість цих речень зумовлює їхню “монолітну” організацію. Специфіка та- 
ких синтаксичних одиниць полягає у відсутності в них синтаксичних зв'язків і семантико-синтаксичних відношень, неможливості утворення чи відтворення ïx за структурними схемами. Структурна типологія нефразеологізованих власне-нечленованих речень грунтується на кількості структурних компонентів та їхній морфологічній природі.

За формальним критерієм нефразеологізовані власне-нечленовані речення $\epsilon$ однокомпонентними реченнєвими побудовами, напр.: - Kyди прямуєте? До Сент-Тропе. - Прошу паспорт. Чи здаєте щзось у багаж? - $\boldsymbol{H i}$. - Ось ваші квитки (І. Йосипів); - Ти таниювала сьогодні просто божественно! Зовсім не так, як хотілося. Страшенно хвилювалася. Все зіпсувала. - Неправда! Краще танцюювати не можна! (П. Загребельний).

Структуру фразеологізованих речень 3 тавтологійними компонентами потрібно описувати, спираючись на такі критерії: морфологічна природа постійного і змінного компонентів та позиція постійного компонента ${ }^{20}$.

Фразеологізовані тавтологійні речення здебільшого трикомпонентні в структурному плані. Залежно від морфологічної природи постійного компонента ці речення утворюють кілька структурних груп: 1) 3 фразеоприйменниковим комплексом; 2) 3 фразеосполучниковим комплексом; 3) 3 фразеозв'язковим комплексом; 4) 3 фразеоча́стковим комплексом ${ }^{21}$. Напр.: - Бджсла загадка, зірка загадка, а людина хіба ні? - Таємниця з таємниць, - роздумує художник (О. Гончар); Боляче і досадно стало Михайлові. Коли б він винен у иьому... На війні як на війні. Все буває (М. Стельмах); А я Тетяну Олексївну вже умовив - хай іде хлопецьь завтра до школи. Діти с діти (А. Дімаров); От молодець, так молодець! (В. Винниченко).

За формальним принципом напівфразеологізовані речення поділені на структурні типи, виділені за такими критеріями, як кількість компонентів у складі фразеокомплексу, морфологічне вираження постійного і змінних компонентів та позиція постійного компонента. Залежно від позиції постійного компонента напівфразеологізовані речення становлять два типи: 3 правобічним залежним і ліво-, правобічним залежними компонентами. За кількісним наповненням фразеокомплекси у структурі напівфразеологізованих речень бувають дво-, три-, чотири- і п’ятимісні. Напр.: Що то мати! (Панас Мирний); - B лікарню б його. - Яка тут лікарня!.. - буркнув Світличний (А. Дімаров); ,, $\boldsymbol{A x}$ ти ж⿻, гадино солона! Скільком людям ти життя поламав, зруйнував, спустошив щзастя..." (М. Стельмах); Нема коли й [жінку] пожаліти (Л. Костенко); Ох цеей мені вже дід! (Я. Лижник).

У частко́во фразеологізованих реченнях фразеологізованою є тільки перша частина, оскільки правобічну позицію заповнює формально-граматичне речення. У цих реченнях фразеосполучниковий чи фразеоча́стково-сполучниковий комплекс має чітко визначену позицію: фразеологізована нерозкладна єдність займає препозицію в реченні, а сполучник починає його другу частину. Фразеологізована єдність може об'єднувати три або чотири компоненти.

За кількістю компонентів фразеосхеми, їхнім морфологічним вираженням виокремлені структурні типи частко́во фразеологізованих речень 3 дво-, триi чотиримісним фразеосполучниковим чи фразеоча́стково-сполучниковим

20 М. І. Личук, Формально-структурні типи фразеологізованих речень з тавтологійними компонентами, [в:] „Наук. часопис Нац. пед. ун-ту ім. М. П. Драгоманова. Сер. 10. Проблеми граматики і лексикології української мови”, зб. наук. праць, відп. ред. М. Я. Плющ, Київ 2015, вип. 12 , с. 158 .

${ }^{21}$ Там само. 
комплексом. Напр.: Диво, як не бачить Микола Яновський найелементарніших речей (Ю. Мушкетик); Робота роботою, але по роботі, вечером, як почнеся було гуляння, то було на щзо надивитися (І. Франко); Не було родини, щоб не лежали усі покотом (У. Самчук); Не встиг отець Аркадій умитись, як з села прийшла делегація (Ірина Вільде).

Семантична типологія нефразеологізованих власне-нечленованих і фразеологізованих речень з тавтологійними компонентами та напівфразеологізованих речень опирається на категорійні значення. Типи цих значень впливають на формування фразеосинтаксичного значення фразеологізованих тавтологійних і напівфразеологізованих речень.

Категорійне значення нефразеологізованих власне-нечленованих речень — “відношення”, що виявляється в ставленні мовця до повідомлюваного, до одного з учасників комунікації, у характері відношення змісту речення, пов’ язаного (дотичного) зі словом-реченням, до дійсності. Оскільки нефразеологізовані власне-нечленовані речення виражені одним або двома структурними компонентами, то це дає підстави визнати відсутність будь-яких семантичних відношень між компонентами або їхнє нульове вираження. Саме тому виокремлювати типи нефразеологізованих власне-нечленованих речень потрібно, спираючись на типи категорійного значення. Категорійні значення “ствердження", "заперечення” та “волевиявлення” є критеріями виокремлення відповідно до трьох типів нефразеологізованих власне-нечленованих речень: 1) зі значенням “ствердження”; 2) зі значенням “заперечення”; 3) зі значенням “волевиявлення”. Напр., стверджувальний семантичний тип: - Розумієш, про щуо я мовлю? — $\boldsymbol{O}$, так! — підтвердила я... (Н. Шейко-Медведєва); заперечний семантичний тип: - Ви добре знаєте академіка? А про Кучмієнка чули? - Ніколи (П. Загребельний); зі значенням “волевиявлення”: — Годі! годі! - кричить Гонта. Годi, погасає (Т. Шевченко).

Підгрунтям семантичної типології фразеологізованих тавтологійних речень $\epsilon$ диференціація категорійних значеннєвих критеріїв “ствердження" i "оцінка", напр.: - Розпочинай допит, иарю, — відказав Полуботок. - Як так, то й так, - мирно промовив цуар (Р. Іваничук); - I дійсно-справи вони і с справи. Чого тут ображатись? (Брати Капранови). Семантична типологія напівфразеологізованих речень упорядкована на основі категорійних значень “ствердження”, “заперечення”, “оцінка” та “волевиявлення”. Напр., стверджувальний семантичний тип: $\boldsymbol{E}$ чого посміхатись. Адже він [Юрко] знав усе (В. Козаченко); - Це з '̈зд особливий. Тут кожен мусить свою пропозицію виявити. $\boldsymbol{A}$ то ми не розуміємо! (О. Гончар); заперечний семантичний тип: - Мамочко! Я знаю, чим тебе розвеселити. - Не до жсартів (М. Вайно); Воно й справді, на наш крик визирав уже дехто з-за тину, а помогти... Яка там поміч! Хто тоді смів слово проти власті сказать? (М. Малюк); Так я йому й допоміг! (О. Лишега); оцінний семантичний тип: - Хто це написав таку гарну пісню?! - nuтав зворушений Санько в Андрія. — От, брат, пісня, так пісня! (І. Багряний); семантичний тип з категорійним значенням "волевиявлення": - Tак тримати! - капітан передав стерно до мойх рук, а сам почав порпатись у линвах біля щзогли... (Брати Капранови).

Семантична типологія частково фразеологізованих речень визначена їхньою синтаксичною структурою та синтаксичними відношеннями між двома їхніми частинами. У препозитивній частині частково фразеологізованих речень $\epsilon$ фразеосхема як нерозкладний комплекс постійних і змінних компонен- 
тів, у постпозиції - членована вільна реченнєва структура. Синтаксична побудова стає фразеологізованою не тільки через синтаксичну злитість і семантичні трансформації компонентів у препозиції, а також під впливом певних чинників: чітко закріпленої позиції компонентів фразеосхеми, зменшення змінних позицій і структурного підрівнювання частин речення. Синтаксична семантика частково фразеологізованих речень зосереджена у сфері певних семантикосинтаксичних відношень. За типом синтаксичних відношень між двома частинами нечленованої побудови вирізняємо такі семантичні типи частково фразеологізованих речень: а) 3 темпоральними відношеннями, напр.: Але не встиг він й вимовить, як захитався, махнув рукою й гепнув додолу лицем (В. Винниченко); б) з відношеннями узагальненої зумовленості, напр.: На те ми, Василю Леонтійовичу, й мужчини, щоб тую гарну полонянку з ворожої неволі визволяти (Б. Лепкий); в) з пояснювальними відношеннями, напр.: Щастя, щи дитина на пелінку якось зачепилась та й на колу повисла (Срібна книга казок); г) з аплікативними відношеннями, напр.: Грix не гріx, a береженого й Бог береже, Маковею (О. Гончар).

Отже, структурно-семантична типологія синтаксично нечленованих словосполучень і синтаксично нечленованих речень репрезентує ієрархізацію синтаксично нечленованих одиниць сучасної української мови. Основою двовимірної типології синтаксично нечленованих одиниць $є$ тип як ідеалізована модель. Типологійна домінанта має двоякий вияв - структурний і семантичний.

\section{Список використаної літератури}

Балко М. В., Актуальні проблеми теорї словосполучення сучасної украӥнської мови, Дніпропетровськ 2014.

Балко М. В., Семантико-синтаксичні і структурні аспекти цілісних словосполучень сучасної украӥнської мови, дис. ... канд. філол. наук, Запоріжжя 2004.

Виноградов В. В., Вопросы изучения словосочетаний, [в:] „Вопросы языкознания”, 1954, № 3, с. 3-24.

Вихованець I. Р., Граматика української мови: Синтаксис, Київ 1993.

Горпинич В. О., Нерозкладні синтаксичні словосполучення в українській мові, [в:] „Українська мова і література в школі”, 1988, № 7, с. 69-70.

Загнітко А. П., Теоретична граматика української мови. Синтаксис, Донецьк 2001.

Личук М. І., Формально-структурні типи фразеологізованих речень з тавтологійними компонентами, [в:] „Наук. часопис Нац. пед. ун-ту ім. М. П. Драгоманова. Cер. 10. Проблеми граматики і лексикології української мови”, зб. наук. праць, відп. ред. М. Я. Плющ, Київ 2015, вип. 12, с. 156-163.

Прокопович Н. Н., Об устойчивых сочетаниях аналитической структуры в русском языке советской эпохи, [в:] Мысли о современном русском языке, ред. В. В.Виноградов, Москва 1969, с. 47-57.

Русская грамматика: Синтаксис, в 2 томах, гл. ред. Н. Ю.Шведова, Москва 1980, т. 2. Шульжук К. Ф., Синтаксис української мови, Київ 2004.

Kruisinga E., Hand book of Present-day English Noordhoff, Groningen 1931.

Ries I., Was ist syntax (ein kritischer Versuch), Marburg 1894.

\section{Spysok vykorystanoi literatury [References]}

Balko M. V., Aktualni problemy teorii slovospoluchennia suchasnoi ukrainskoi movy [Topical Problems of Word Combination Theory of Modern Ukrainian], Dnipropetrovsk 2014. 
Balko M. V., Semantyko-syntaksychni i strukturni aspekty tsilisnykh slovospoluchen suchasnoi ukrainskoi movy [Semantic, Syntactic and Structural Aspects of Integral Word-Combinations of Modern Ukrainian], dys. ... kand. filol. nauk, Zaporizhzhia 2004.

Vinogradov V. V., Voprosy izuchenija slovosochetanij [Issues on Word-Combinations Learning], [v:] „Voprosy jazykoznanija”, 1954, № 3, s. 3-24.

Vykhovanets I. R., Hramatyka ukrainskoi movy: Syntaksys [The Ukrainian Language Grammar], Kyiv 1993.

Horpynych V. O., Nerozkladni syntaksychni slovospoluchennia v ukrainskii movi [Stable Syntactic Word-Combinations in Ukrainian], [v:] „Ukrainska mova i literatura v shkoli”, 1988, № 7.

Zahnitko A. P., Teoretychna hramatyka ukrainskoi movy. Syntaksys [Theoretical Grammar of the Ukrainian Language. Syntax], Donetsk 2001.

Lychuk M. I., Formalno-strukturni typy frazeolohizovanykh rechen $z$ tavtolohiinymy komponentamy [Formal Structural Types of Phraseological Sentences with Tautological Components ], [v:] „Nauk. chasopys Nats. ped. un-tu im. M. P. Drahomanova. Ser. 10. Problemy hramatyky i leksykolohii ukrainskoi movy”, zb. nauk. prats, vidp. red. M. Ya. Pliushch, Kyiv 2015, vyp. 12, s. 156-163.

Prokopovich N. N., Ob ustojchivyh sochetanijah analiticheskoj struktury v russkom jazyke sovetskoj jepohi [On Stable Combinations of Analytic Structure in the Russian Language of the Soviet Period], [v:] Mysli o sovremennom russkom jazyke, red. V. V. Vinogradov, Moskva 1969, s. 47-57.

Russkaja grammatika: Sintaksis [The Russian Language Grammar: Syntax], v 2 tomah, gl. red. N. Ju. Shvedova, t. 2, Moskva 1980.

Shulzhuk K. F., Syntaksys ukrainskoi movy [The Ukrainian Language Syntax], Kyiv 2004.

Kruisinga E., Hand book of Present-day English Noordhoff, Vol. 3, Groningen 1931.

Ries I., Was ist syntax (ein kritischer Versuch), Marburg 1894. 